\title{
Bottom contact behaviour by humpback whales in Brazilian waters: first underwater observations at Trindade Island
}

\author{
Flavia C. Frizzera Pinheiro ${ }^{1,2^{*}}$, Hudson T. Pinheiro ${ }^{2,3,4}$, Salvatore Siciliano ${ }^{5,6}$ and Robson G. Santos ${ }^{7}$
}

\begin{abstract}
Few records of humpback whales (Megaptera novaeangliae) have been made in Brazilian oceanic waters. This article reports the first record of bottom contact behaviour by humpback whales in Brazilian waters and adds four new sightings of the species to Trindade, an island located $1160 \mathrm{~km}$ from the Brazilian coast. The bottom contact behaviour has been associated with moult and hygienic functions for some cetaceans. The change of water temperature, triggered by the migration from cold Antarctic waters to the warm tropical Trindade coast, could have accelerated the turnover of skin superficial layers and the moulting process to this humpback whale here reported. Despite such uncertain reason of the behaviour, this novel record comes to increase the behavioural repertoire for the humpback whales in Brazilian waters, may be possibly an additional cleaning strategy.
\end{abstract}

Keywords: Humpback whale, Cleaning strategy, Megaptera novaeangliae, Novel behaviour

\section{Background}

The humpback whale, Megaptera novaeangliae, is found in all oceans, however, its distribution pattern is linked to migratory movements (Zerbini et al. 2006). This species uses polar zones as feeding grounds in the summer, and tropical and sub-tropical zones as mating and calving grounds in the winter (Zerbini et al. 2004). There are seven geographically separated populations distributed along the southern hemisphere (Zerbini et al. 2006). Abrolhos Bank, situated in the Brazilian coast, is the most important breeding ground for humpback whales in the South-Western Atlantic (Martins et al. 2001), besides that, compared with the platform shelf, few records of humpback whales were made in Brazilian oceanic waters. However, Trindade Island $\left(20^{\circ} 30^{\prime} 30^{\prime \prime} \mathrm{S}, 2^{\circ} 19^{\prime}\right.$ $30^{\prime \prime} \mathrm{W}$ ), located at $1160 \mathrm{~km}$ from Brazilian coast (Fig. 1), annually receives these whales in its surrounding waters (Siciliano et al. 2012). Humpback whales were recorded in Trindade Island surroundings since the whaling period, in the XIX century (Townsend 1935). The

\footnotetext{
* Correspondence: flaviacarnelli@hotmail.com

${ }^{1}$ Departamento de Oceanografia e Ecologia, Universidade Federal do Espírito Santo, Vitória, ES 29075-910, Brazil

${ }^{2}$ Associação Ambiental Voz da Natureza, Vitória, ES 29050-780, Brazil

Full list of author information is available at the end of the article
}

presence in Trindade Island as a migratory destination of humpback whales was discussed by Siciliano (1997), which reported 16 sightings from 1984 to 1994 . More recently, Siciliano et al. (2012) added seven new sightings for Trindade Island and suggested the island as a migratory route for humpback whales that visit Brazilian waters. This note reports the first record of bottom contact behaviour by humpback whales in Brazilian waters and adds four new sightings of the species at Trindade Island (Fig. 1).

\section{Methods}

These sightings were made between May 25 and June 17, 2009, probably, representing the earlier migrants arriving for the breeding season off Brazil, which normally occurs between July and November (Siciliano 1997; Morete et al. 2007). All four sighting records were made opportunistically from different sites of the island (Fig. 1). During two occasions, a closer approximation to the whales was possible using an inflatable boat. Behavioural descriptions were based on the method ad libitum, collected from the boat and underwater observations by free diving. 


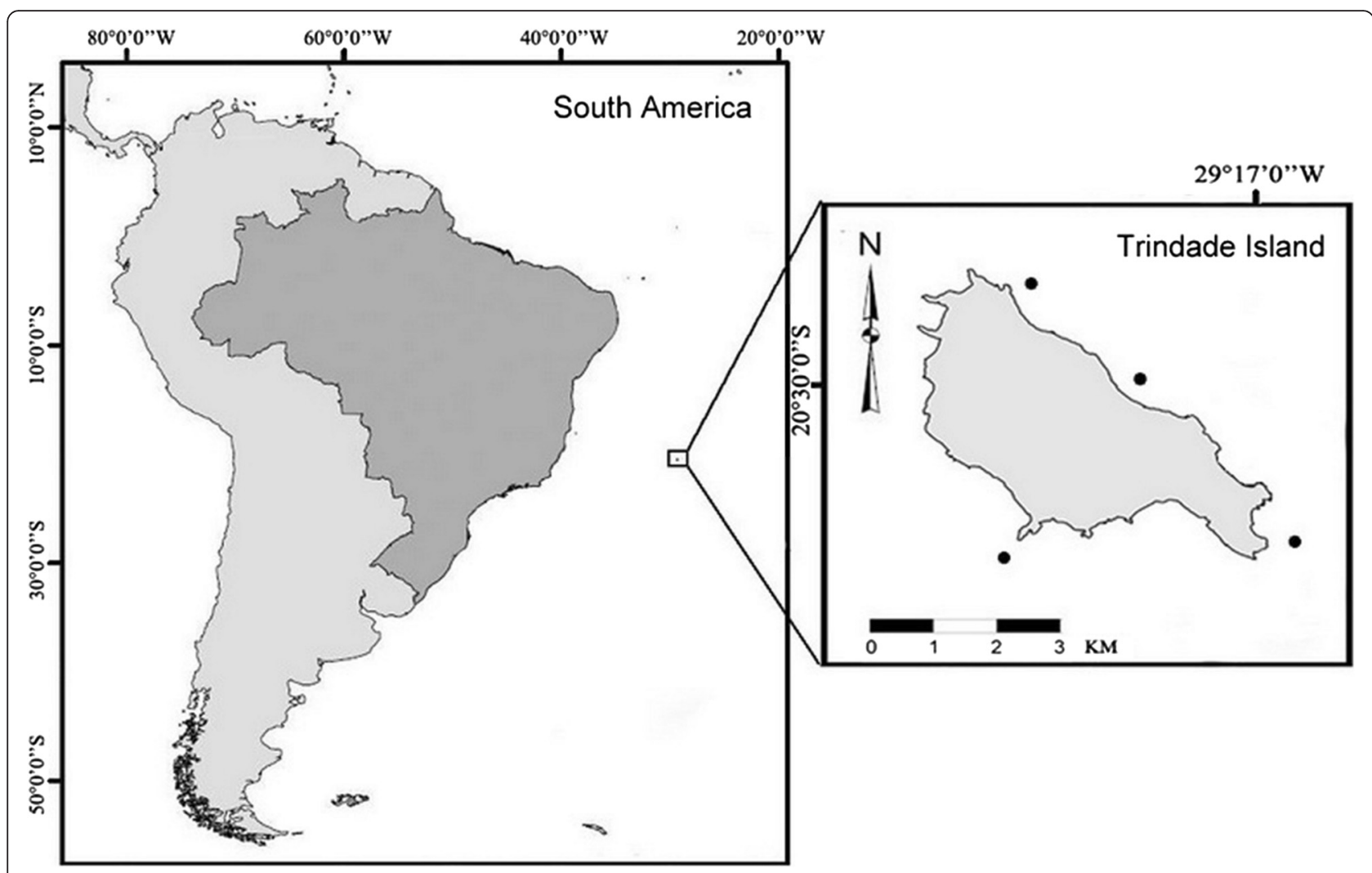

Fig. 1 Map of Trindade Island, off the Brazilian Central Coast, indicating the four sightings of humpback whale made between May 25 and June 17, 2009

\section{Results}

On May $25^{\text {th }}$, 2009, two humpback whales were sighted swimming slowly towards the east part of the island. A third record was made on May $28^{\text {th }}$ swimming for almost the entire island's perimeter. In the morning, it was observed swimming slowly on the west side and contouring the south face, and in the afternoon it passed by the east part of the island. This whale was sighted breaching and lobtailing for several times. The fourth record, an adult c. $12 \mathrm{~m}$ of total length (visually estimated during the free-diving activity), was observed on June $17^{\text {th }}$ for $1 \mathrm{~h}$ while it was swimming slowly presenting a constant flipper slapping behaviour only interrupted by 3-5 min dives (Fig. 2). In one of these dives, the whale was rubbing its dorsal region against the sand (35 $\mathrm{m}$ depth) for at least $20 \mathrm{~m}$. The water visibility was

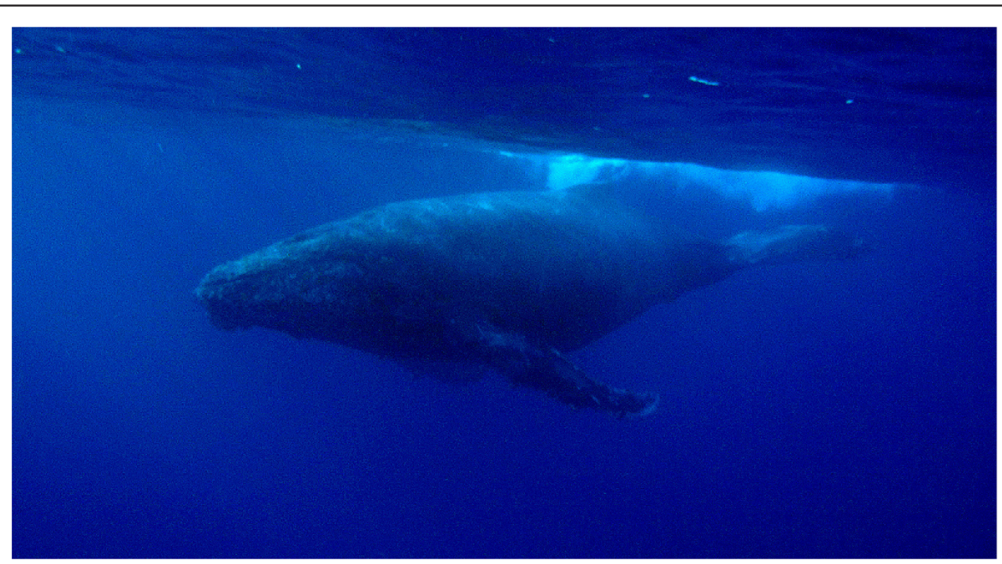

Fig. 2 Underwater photograph of the fourth individual humpback whale, c. $12 \mathrm{~m}$ in total length, observed at Trindade Island, on June $17^{\text {th }}, 2009$. Note the high visibility of the waters surrounding Trindade Island. Photo by Hudson T. Pinheiro 
higher than $50 \mathrm{~m}$, where was clearly possible to observe its whitish underbody turned up and the back scuffing on the sand bottom.

\section{Discussion}

The bottom contact behaviour observed in cetaceans is mainly related to cleaning or feeding functions. This behaviour was already related to feeding strategy for bottlenose in Bahamas (Rossbach and Herzing 1997), for estuarine dolphins in Brazil (Rossi-Santos and Wedekin 2006) and humpback whales in North Atlantic (Hain et al. 1995). However, the feeding hypothesis is less probable due to the rare records of feeding by humpback whales in Brazilian waters (Alves et al. 2009), considered only as a breeding ground (Zerbini et al. 2004).

On the other hand, there are records of cetaceans rubbing their skin on sand, mud, pebble and limestone substrate near shore, a behaviour associated with moult (Smith et al. 1992) and hygienic functions (Dudzinski 1998). According to Smith et al. (1992), the seasonal variation of water temperature accelerates the turnover of superficial layers in belugas, where the whales rub themselves on the bottom, a process that appears to help the moult. This process is so far unknown in other cetaceans, but might have happened in the humpback whale here reported, since it probably had just migrated from the cold Antarctic waters to the warm tropical Trindade coast. Moreover, the flipper slap behaviour initially observed for this forth individual could be also related to the cleaning/moult process as well. This behaviour is commonly considered a form of communication, in order to maintain acoustic contact between humpback whales (Herman and Tavolga 1980). However, the expected low numbers of whales around Trindade in that period decreases the possibility of communication purposes. Despite such uncertain reason of the behaviour, this novel record comes to increase the behavioural repertoire for the humpback whales in Brazilian waters and may represent an additional cleaning strategy.

\section{Conclusions}

Despite several studies conducted in shallow waters of Brazil (e.g. Abrolhos Bank), no information of a similar behaviour was observed among humpback whales yet, where just the breaching behaviour is suggested for cleaning function in Brazil (Morete et al. 2003). Thus, these observations also call attention for the possibilities of underwater behavioural studies at Trindade Island, favoured by the short platform and clear water that it presents. Whether Trindade Island is a cleaning station to the humpback whales in its migratory route, or whether the bottom contact behaviour is just an unusual behaviour, it is still need clarification, and future work is necessary to a better assessment and understanding of their behavioural repertoire.

\section{Acknowledgements}

The authors thank TAMAR Project/ICMBio and Brazilian Navy for logistic support. We also thank Lisa Oliveira and Leonardo M. Schuler for comments.

\section{Declaration}

All the data is available in the body of the manuscript.

List of Abbreviations is not applicable.

This research received no specific grant from any funding agency, commercial or non-profit sectors.

\section{Authors' contributions}

HTP and RGS collected the data, FCFP led the writing of the manuscript and all authors analysed the data and reviewed the manuscript. All authors read and approved the final manuscript.

\section{Competing interests}

The authors declare that they have no competing interests.

\section{Author details}

1 Departamento de Oceanografia e Ecologia, Universidade Federal do Espírito Santo, Vitória, ES 29075-910, Brazil. ²Associação Ambiental Voz da Natureza, Vitória, ES 29050-780, Brazil. Department of Ecology and Evolutionary Biology, University of California Santa Cruz, Santa Cruz, CA 95062, USA. ${ }^{4}$ California Academy of Sciences, San Francisco, CA 94118, USA. ${ }^{5}$ Instituto Oswaldo Cruz/FIOCRUZ, Rio de Janeiro, RJ 21040-360, Brazil. ' Instituto Megafauna Marinha (IMMAR)/Grupo de Estudos de Mamíferos Marinhos da Região dos Lagos (GEMM-Lagos), Praia Seca, Araruama, RJ, Brazil. ' Instituto de Ciências Biológicas e da Saúde, Universidade Federal de Alagoas, Maceió, Alagoas, Brazil.

Received: 6 June 2016 Accepted: 8 June 2016

Published online: 27 July 2016

\section{References}

Alves CP, Andriolo A, Zerbini A, Pizzorno LA, Clapham P. Record of feeding by humpback whales (Megaptera novaeangliae) in tropical waters off Brazil. Mar Mamm Sci. 2009;25(2):416-9.

Dudzinski KM. Contact behavior and signal exchange in Atlantic spotted dolphins (Stenella frontalis). Aquat Mamm. 1998;24(3):129-42.

Hain HW, Ellis SL, Kenney RD, Clapham PJ, Gray BK, Weinrich MT, et al. Apparent bottom feeding by humpback whale on Stellwagen Bank. Mar Mamm Sci. 1995;11(4):464-79.

Herman LM, Tavolga WN. The communication systems of cetaceans. In: Herman LM, editor. Cetacean behavior: Mechanisms and functions. New York: Wiley Interscience; 1980. p. 149-209.

Martins CA, Morete ME, Engel MH, Freitas AC, Secchi ER, Kinas PG. Aspects of habitat use patterns of humpback whales in the Abrolhos Bank, Brazil, breeding ground. Queensland Mus Mem. 2001;47(2):563-70.

Morete ME, Pace RM, Martins CA, Freitas AC, Engel MH. Indexing seasonal abundance of humpback whale around Abrolhos Archipelago, Bahia, Brazil. Lat Am J Aquat Mamm. 2003:2(1):21-8.

Morete ME, Bisi TL, Rosso S. Temporal pattern of humpback whale (Megaptera novaengliae) group structure around Abrolhos Archipelago breeding region, Bahia, Brazil. J Mar Biol Assoc U K. 2007;87:87-92.

Rossbach KA, Herzing DL. Underwater observations of benthic-feeding bottlenose dolphins (Tursiops truncatus) near Grand Bahama Island, Bahamas. Mar Mamm Sci. 1997;13:498-504.

Rossi-Santos M, Wedekin LL. Evidence of bottom contact by estuarine dolphins (Sotalia guianensis) on the Eastern Coast of Brazil. Aquat Mamm. 2006;32(2):140-4.

Siciliano S. Características da população de baleias jubarte (Megaptera novaeangliae) da costa brasileira, com especial referência aos Bancos de Abrolhos, MSc Thesis. Brazil: Universidade Federal Rural do Rio de Janeiro; 1997. p. 113.

Siciliano S, Moura JF, Filgueiras HR, Rodrigues PP, Leite NO. Sightings of humpback whales on the Vitória-Trindade Chain and around Trindade Island, Brazil. Braz J Oceanogr. 2012;60(3):455-9.

Smith TG, St. Aubin DJ, Hammill MO. Rubbing behaviour of belugas, Delphinapterus leucas, in a high Arctic estuary. Can J Zool. 1992;70(12):2405-9.

Townsend $\mathrm{CH}$. Distribution of certain whales as shown by logbook records of American whaleships. Zoologica. 1935;19:1-50. 
Zerbini A, Andriolo A, Rocha JM, Simöes-Lopes PC, Siciliano S, Pizzorno JL, et al. Winter distribution and abundance of humpback whales (Megaptera novaeangliae) off Northeastern Brazil. J Cetacean Res Manag. 2004;6(1):101-7.

Zerbini AN, Andriolo A, Heide-Jørgensen MP, Pizzorno JL, Maia YG, VanBlaricom $G R$, et al. Satellite-monitored movements of humpback whales Megaptera novaeangliae in the Southwest Atlantic Ocean. Mar Ecol Prog Ser. 2006;313: 295-304.

Submit your next manuscript to BioMed Central and we will help you at every step:

- We accept pre-submission inquiries

- Our selector tool helps you to find the most relevant journal

- We provide round the clock customer support

- Convenient online submission

- Thorough peer review

- Inclusion in PubMed and all major indexing services

- Maximum visibility for your research

Submit your manuscript at www.biomedcentral.com/submit 